\title{
Research on picture books: A comparative study of Asia and the World
}

\author{
Jia-Fen Wu \\ School of Education, Jinggangshan University \\ 28 Xueyuan Road., Ji'an City, Jiangxi Province, 343009, P.R. CHINA \\ E-mail: omamakat@qq.com
}

\begin{abstract}
A bibliometric analysis of scholarly articles on picture books between 1992 and 2017 portrays both the worldwide and Asian trends based on the development of picture book research for the past 26 years. The findings are based on an analysis of 21,450 references to 619 articles on picture books in 295 journals indexed by the Web of Science. Four composite themes consistently emerge from the analysis are: (a) Reading intervention for young children; (b) Toddlers' transference through picture book illustrations to the real world; (c) gender equity issues; and (d) Special education concerns. The first two themes centre on early childhood education, whereas the other two focus on human rights. The potential themes in 80 articles, taken from 65 journals, present the inherent characteristics/features found in picture book research among 12 Asian countries. Although results present four core themes that have formed worldwide on the topic over the past 26 years, there are five specific themes generated in the context of this topic in Asia, along with three common themes. Computer-assisted instruction and educational technology are seen to be a potential trend in future picture book research related to Asia.
\end{abstract}

Keywords: Bibliometrics; Picture books; Illustration books; Publication trends; Histcite.

\section{INTRODUCTION}

Picture books are books that adults, parents, teachers or caregivers, read to children or younger children. Picture books use illustrations to both represent content and support story-telling. Because of the connection between pictures and readers' feelings, adults reading picture books can directly feel the emotional content of pictures (Bang 2000). To date, related topics on preschool education are still the mainstream of most picture book 
research. In past studies, scholars have been interested with interaction between both adults, either parents or primary caregivers, and infants or young children during jointreading of picture books (Devescovi and Baumgartner 1993; Danis, Bernard and Leproux 2000), especially as it relates to the power of reading for enhancing literacy abilities of children from low-income families (Neuman and Celano 2001; Gorman et al. 2011; Chen and Pan 2009). Researchers have also focused on how picture books provide young children with verbal and nonverbal scaffoldings via texts and illustrations and the observation of how young readers transfer the knowledge gained in picture books into real life takes place (Ganea, Pickard and DeLoache 2008; Ganea et al. 2009; Ganea, Ma and DeLoache 2011). In addition, picture books are frequently utilized in special education or counseling because of their interpretive formatting (Tager-Flusberg and Sullivan 1995; Renz et al. 2003; Norbury and Bishop 2009). Based on joint reading which constitutes a child-adult dual readership, the multiple readerships which take place have recently been found to prove picture books to be equally suitable for adult readers (Suzuki et al., 2014; Murayama et al. 2015; Sun 2015; Sakurai et al. 2016; An, Wang and Sung 2017).

In the past two decades, most of the important publications and prolific writers related to picture book research were found to be from western countries, whereas relatively little attention has been paid to the development of picture book studies in the Asian context. It is worth exploring to the extent that Asian scholars choose to conduct research on picture books in the region; this includes their individual research interests, potential developments, and future trends as foreseen. Taking this into consideration, the purpose of this bibliometric study is to analyze data regarding picture book research based on datasets from the Web of Science (WoS) in a span of 26 years from 1992 to 2017. Specifically, the objective of this study is to gauge the trends in picture book research based on the following indicators:

(a) The annual output of publications in the world and in Asia.

(b) The geographic distributions on picture book research in the world and in Asia, including the top five countries with the most publications, the most commonly cited journals, the most prolific authors, as well as the most cited articles.

(c) A comparison of core issues related to picture book research in both Asia and the world.

(d) The potential future trends of picture book research in Asia and the world. 


\section{METHOD}

The data for this study were retrieved from three primary sources i.e. The Science Citation Index-Expanded (SCI-E), the Social Sciences Citation Index (SSCI), and the Arts \& Humanities Citation Index (A\&HCl) available through the Web of Science (WoS) database, retrieved on March $3^{\text {rd }}$ 2018. The terms "picture book*" or "picturebook*" were set as the search language to search for journal articles and conference papers. The timespan was set as "ALL YEAR" in order to thoroughly obtain relevant past data. This returned a search output of 619 articles, representing 1,357 authors in the 295 journals that were examined. A total of 21,450 references with 1,871 keywords are included in the titles and abstracts represented. The retrieved data from WoS were analyzed by use of HistCite, a software for analyzing and visualizing bibliometric maps related to citation linkages between scientific papers (Van Eck and Waltman 2009). The following data collected for the purpose of this study were exported to the HistCite software package to be analyzed: Records of publications; keyword; authors' names; titles; journals/sources; publication dates; abstracts; document types; languages used in publication; country/ territories covered; institution/ institutions with subdivisions; cited references; Total Location Citation Score (TLCS) which is the total number of citations from authors in the field within the collected datasets.; and Total Global Citation Score (TGCS) which refers to the total citations in the WoS to papers by the authors in the collected datasets.

\section{RESULTS}

\section{Distribution of Publications}

\section{(a) Yearly Output}

Table 1 presents the time and the number of publications related to picture books on an annual basis within both Asia and the World between 1992 and 2017. There were in total 619 articles collected and 80 articles by Asian authors were selected. All the 619 articles were given the running number from [1] to [619] and indicated subsequently. The very first article about picture book research indexed in the WoS was published in 1992, a total of nine published in that particular year.

The publication growth rate from 1992 to 2007 remained relatively stagnant, with two minor peaks occurring in 1996 and 2004. This field of research continued to flourish from 2008 onwards. Since 2008, the literature growth rate reached 27 papers and then dramatically increased $\left(R^{2}=0.7256\right.$, Figure 1$)$. In Asia, the first paper on picture book research appeared in 1992 and the publication remained largely stagnant from 1992 to 2013. In 2015, the volume of papers published in Asia was only one-seventh of the volume published by the 
rest of the world. By 2016, the ratio was one-sixth, and it continued to become one-fourth in 2017. In a word, the publication rate flourished since 2014 and gradually increased $\left(R^{2}=\right.$ 0.5183 , Figure 1).

Table 1: Yearly Output of Research on Picture Books between 1992 to 2017 (Asia vs. World)

\begin{tabular}{c||c||c||c||c|c}
\hline \hline \multirow{2}{*}{ Year } & \multicolumn{2}{c||}{ No. of articles } & \multirow{2}{*}{ Year } & \multicolumn{2}{c}{ No. of articles } \\
\cline { 2 - 3 } & Asia & World & & Asia & World \\
\hline \hline 1992 & 1 & 8 & 2005 & 2 & 14 \\
\hline \hline 1993 & 0 & 11 & 2006 & 2 & 15 \\
\hline \hline 1994 & 1 & 12 & 2007 & 1 & 9 \\
\hline \hline 1995 & 0 & 8 & 2008 & 2 & 27 \\
\hline \hline 1997 & 2 & 16 & 2009 & 1 & 28 \\
\hline \hline 1999 & 0 & 10 & 2010 & 4 & 23 \\
\hline \hline 2000 & 0 & 9 & 2011 & 4 & 37 \\
\hline \hline 2001 & 0 & 13 & 2012 & 7 & 39 \\
\hline \hline 2002 & 1 & 7 & 2013 & 5 & 42 \\
\hline \hline 2003 & 0 & 14 & 2014 & 11 & 56 \\
\hline \hline
\end{tabular}

\section{(b) Geographic Distribution}

Geographic distribution consists of the country/ territory of origin, author distribution, and source distribution. Table 2 presents the distribution of the countries/regions by numerical order of publications in WoS. A total of 48 countries were collected and only the top-four countries and the 12 countries in Asia were listed in Table 2. The United States, ranking first in this list, has contributed 326 articles, or 52.7 percent of articles related to picture books; followed by Canada (57, 9.2\%); the UK (51, 8.2\%); and Australia (48, 7.8\%). Listings for Asian countries were considerably lower. For example, when compared with other countries in Asia, Taiwan is ranked $5^{\text {th }}$ in the world $(20,3.2 \%)$, followed by Japan $\left(6^{\text {th }}, 17\right.$ articles, $\left.2.7 \%\right)$, Turkey $\left(10^{\text {th }}, 14\right.$ articles, $\left.2.3 \%\right)$, and the People's Republic of China $\left(13^{\text {th }} .10,1.6 \%\right)$. 


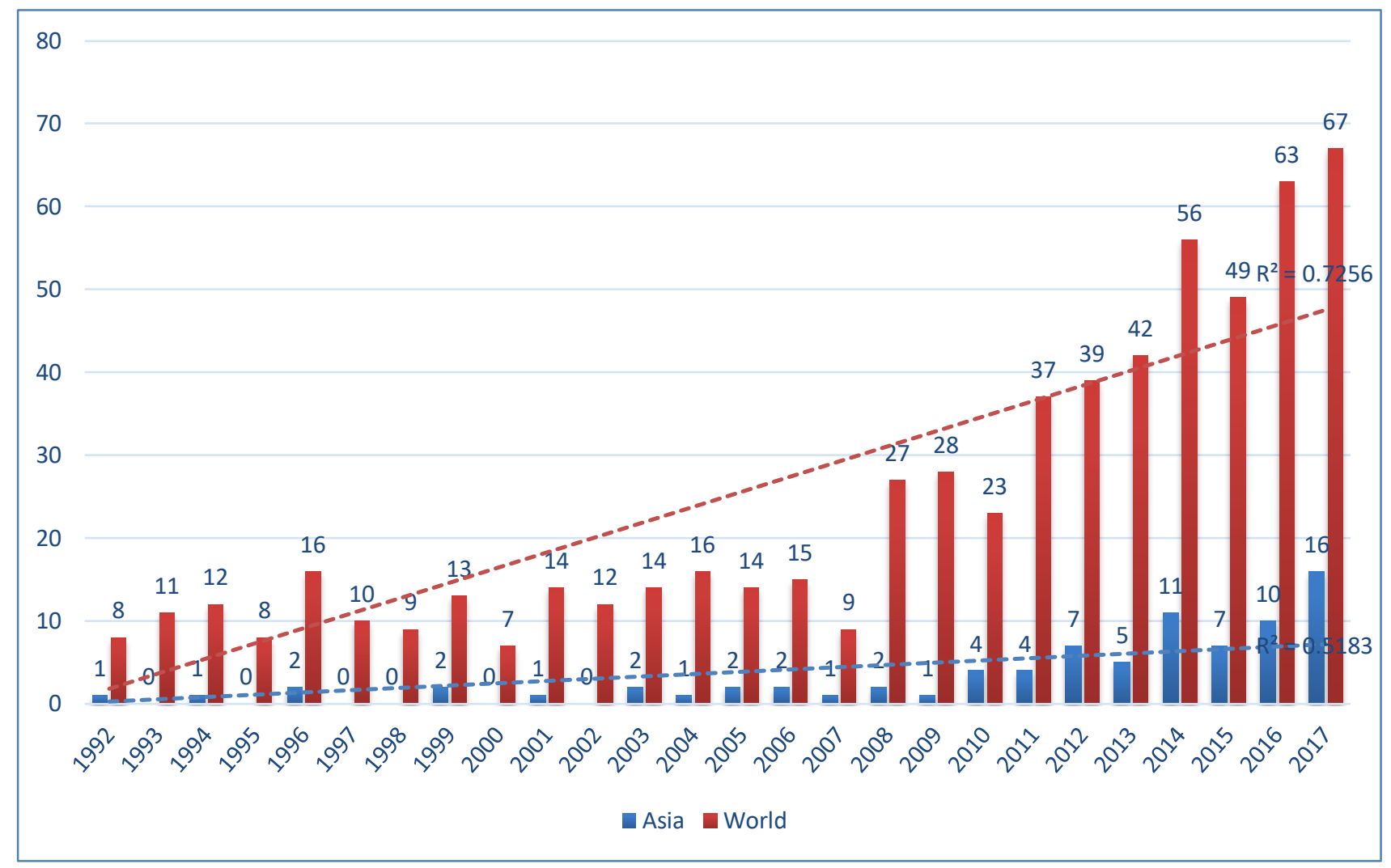

Figure 1: The Distribution of Annual Publication of Research on Picture Books Indexed in the Web of Science (1992-2017)

As to the examination of the publications on picture books only by Asian authors, there are a total of 80 articles published in 65 journals, excluding two joint articles (Singaporean and Taiwanese scholars together for article [395], Mainland Chinese and South Korean scholars for article [587)). In this grouping, Taiwan ranks first in Asia with an author contribution of 20 research papers (25\%), followed by Japan (17 articles, $21 \%$ ), Turkey $(14,17.5 \%)$, the People's Republic of China (10 articles, 12.5\%), and South Korea (6 articles, $7.5 \%$ ); whereas there are six countries recording less than 2 articles each.

TLCS represents the influence of a given article in the field of picture book research. Findings in Table 2 indicate that the research articles published from four countries (USA, Canada, UK and Australia) were most cited in other authors' work. USA has the highest TLCS for picture book research in the world; even when compared with the sum of all papers published in Canada, the UK, Australia, and Taiwan. It should be noted that Taiwan has yielded a higher TLCS than other Asian countries. TGCS refers to the total citations in the WoS to papers by the authors in the collected datasets. When compared by TGCS, USA has the highest score, followed by UK, Canada, Australia, and Japan. 
Table 2. Geographic Distribution of Research on Picture Books Indexed in the Web of Science (1992-2017)

\begin{tabular}{|c|c|c|c|c|c|c|}
\hline World rank & Country & Articles & World (\%) & Asia (\%) & TLCS & TGCS \\
\hline 1 & USA & 326 & 52.7 & - & 562 & 5342 \\
\hline 2 & Canada & 57 & 9.2 & - & 60 & 671 \\
\hline 3 & UK & 51 & 8.2 & - & 46 & 841 \\
\hline 4 & Australia & 48 & 7.8 & - & 84 & 465 \\
\hline 5 & Taiwan & 20 & 3.2 & 25 & 11 & 66 \\
\hline 6 & Japan & 17 & 2.7 & 21 & 2 & 104 \\
\hline 10 & Turkey & 14 & 2.3 & 17.5 & 2 & 23 \\
\hline 13 & People's R. China & 10 & 1.6 & 12.5 & 2 & 48 \\
\hline 16 & Israel & 7 & 1.1 & 8.75 & 3 & 47 \\
\hline 18 & South Korea & 6 & 1 & 7.5 & 1 & 10 \\
\hline 27 & Cyprus & 2 & 0.3 & 2.5 & 0 & 10 \\
\hline 31 & Singapore & 2 & 0.3 & 2.5 & 0 & 3 \\
\hline 38 & Indonesia & 1 & 0.2 & 1.25 & 0 & 2 \\
\hline 39 & Iran & 1 & 0.2 & 1.25 & 1 & 6 \\
\hline 42 & Malaysia & 1 & 0.2 & 1.25 & 0 & 1 \\
\hline 44 & Pakistan & 1 & 0.2 & 1.25 & 1 & 6 \\
\hline
\end{tabular}

\section{(c) Authorship Distribution}

Table 3 and Table 4 list the most cited authors ranked by their number of articles (publication productivity) and TLCS respectively. In Table 3, Ganea, P. A. published 10 articles and is ranked first, followed by Barr, R. and Pantaleo, S. (9 articles each), Serafini, F. (8 articles) and three authors others (Peña, E.D., Simcock, G. and DeLoache, J.S), publishing 7 articles respectively On the contrary, when ranked based on TLCS, DeLoache, J.S. who published 7 articles is in the top position (122 TLCS), followed by Ganea, P.A. (84 TLCS), the most productive author in picture book research. Some authors, who published only one article each, are listed in Table 4 because of their higher TLCS (such as Pickard, M.B., Demarest, J., Kortenhaus, C.M. and Ma, L.L., and have been regarded as the most cited authors in the field of picture book research. 
Table 3: Most Cited Authors by Publication Productivity (1992-2017)

\begin{tabular}{l||l||l||c||c||c}
\hline \hline Rank & \multicolumn{1}{|c||}{ Author } & Country & Articles & TLCS & TGCS \\
\hline 1 & Ganea, P.A. & Canada & 10 & 84 & 240 \\
\hline \hline 2 & Barr, R. & USA & 9 & 24 & 137 \\
\hline 3 & Pantaleo, S. & Canada & 9 & 6 & 45 \\
\hline \hline 4 & Serafini, F. & USA & 8 & 3 & 18 \\
\hline 5 & Peña, E.D. & USA & 7 & 24 & 290 \\
\hline \hline 6 & Simcock, G. & Australia & 7 & 59 & 132 \\
\hline \hline 7 & DeLoache, J.S. & USA & 7 & 122 & 332 \\
\hline \hline 8 & Vernon-Feagans, L. & USA & 6 & 2 & 119 \\
\hline \hline 9 & Gillam, R.B. & USA & 4 & 13 & 173 \\
\hline \hline 10 & Houston-Price, C. & Malaysia & 4 & 3 & 85 \\
\hline \hline 11 & Macken-Horarik, M. & Australia & 4 & 1 & 16 \\
\hline \hline 12 & Slimani, N. & France & 4 & 3 & 93 \\
\hline 13 & Whitehurst, G. J. & USA & 4 & 51 & 915 \\
\hline \hline 14 & Wright, H. H. & USA & 4 & 1 & 34 \\
\hline
\end{tabular}

Table 4: Most Cited Authors by Total Location Citation Score (1992-2017)

\begin{tabular}{l||l|l|l|l||c}
\hline \hline Rank & \multicolumn{1}{|c|}{ Author } & Country & Articles & TLCS & TGCS \\
\hline \hline 1 & DeLoache, J.S. & USA & 7 & 122 & 332 \\
\hline \hline 2 & Ganea, P.A. & Canada & 10 & 84 & 240 \\
\hline \hline 3 & Simcock, G. & Australia & 7 & 59 & 132 \\
\hline \hline 4 & Whitehurst, G. J. & USA & 4 & 51 & 915 \\
\hline \hline 5 & Pickard, M. B. & USA & 1 & 40 & 102 \\
\hline \hline 6 & Demarest, J. & USA & 1 & 28 & 49 \\
\hline \hline 7 & Epstein, J. N. & USA & 2 & 28 & 542 \\
\hline \hline 8 & Kortenhaus, C. M. & USA & 1 & 28 & 49 \\
\hline \hline 9 & Angela, L. & USA & 2 & 25 & 582 \\
\hline \hline 10 & Barr, R. & USA & 9 & 24 & 137 \\
\hline \hline 11 & Peña, E.D. & USA & 7 & 24 & 290 \\
\hline \hline 12 & Anderson, D. & USA & 2 & 20 & 83 \\
\hline \hline 13 & Ma, L. L. & Canada & 1 & 20 & 40 \\
\hline \hline
\end{tabular}




\section{(d) Source Distribution}

Table 5 presents the most cited articles (with at least 15 citations) on picture book research during the years under study. The top most cited article authored by Ganea, Pickard, and DeLoache (2008) discussed children's cognitive development when coupled with picture books in an effort to reveal how very young children can transfer between picture books and the real world. In 2011, Ganea, Ma, and DeLoache published another paper regarding young children's learning transfer with picture books. In addition to cognitive development and picture books, the iconicity of picture books was another cogent issue broadly discussed by the scholars. For example, Simcock and DeLoache (2006) published an article about the effects of iconicity on toddlers' reenactment influenced by picture books; and, Ganea et al. (2009) published an article entitled "Toddlers' referential understanding of pictures." Likewise, gender issues such as gender roles and gender stereotypes, are mentioned in the most cited articles authored by Kortenhaus, and Demarest (1993); Hamilton et al. (2006); and Oskamp, Kaufman, and Wolterbeek (1996).

Table 5: Most Cited Articles on Picture book Research Between 1992 and 2017

\begin{tabular}{|c|c|c|}
\hline Rank & Reference to the Article (Authors, Year, Title, Journal, \#Article No) & Citation \\
\hline 1 & $\begin{array}{l}\text { Ganea, P.A., Pickard, M.B., \& Deloache, J.S. (2008). Transfer between picture books } \\
\text { and the real world by very young children, Journal of Cognition and Development, } 9 \\
\text { (1): 46-66. \#196 }\end{array}$ & 40 \\
\hline 2 & $\begin{array}{l}\text { Simcock, G., \& Deloache, J. (2006). Get The Picture? The effects of iconicity on } \\
\text { toddlers' reenactment from picture books, Developmental Psychology, } 42 \text { (6): 1352- } \\
\text { 1357. \#178 }\end{array}$ & 31 \\
\hline 3 & $\begin{array}{l}\text { Kortenhaus, C. M, \& Demarest, J. (1993). Gender-role stereotyping in childrens- } \\
\text { literature - An update, Sex Roles, } 28 \text { (3-4): 219-232. \#11 }\end{array}$ & 28 \\
\hline 4 & $\begin{array}{l}\text { Ganea, P.A., Ma, L.L., \& Deloache, J.S. (2011). Young children's learning and transfer } \\
\text { of biological information from picture books to real animals, Child Development. } 82 \\
\text { (5): 1421-1433. \#291 }\end{array}$ & 20 \\
\hline 5 & $\begin{array}{l}\text { Hamilton, M.C., Anderson, D., Broaddus, M., \& Young, K. (2006).Gender stereotyping } \\
\text { and under-representation of female characters in } 200 \text { popular children's picture } \\
\text { books: A twenty-first century update, Sex Roles, } 55 \text { (11-12): 757-765. \#179 }\end{array}$ & 18 \\
\hline 6 & $\begin{array}{l}\text { Turnerbowker D.M. (1996). Gender stereotyped descriptors in children's picture } \\
\text { books: Does "curious Jane" exist in the literature? Sex Roles, } 35 \text { (7-8): 461-488. \#51 }\end{array}$ & 16 \\
\hline 7 & $\begin{array}{l}\text { Simcock, G., Dooley, M. (2007). Generalization of learning from picture books to novel } \\
\text { test conditions by 18-and 24-month-old children, Developmental Psychology. } 43 \text { (6): } \\
\text { 1568-1578. \#188 }\end{array}$ & 16 \\
\hline 8 & $\begin{array}{l}\text { Oskamp, S., Kaufman, K., Wolterbeek, L.A. (1996). Gender role portrayals in preschool } \\
\text { picture books, Journal of Social Behavior and Personality, } 11 \text { (5): 27-39. \#41 }\end{array}$ & 15 \\
\hline 9 & $\begin{array}{l}\text { Ganea, P.A., Preissler, M.A., M.L., Butler, L., Carey, S., Deloache, J.S. (2009). Toddlers' } \\
\text { referential understanding of pictures, Journal of Experimental Child Psychology, } 104 \\
\text { (3): 283-295. \#237 }\end{array}$ & 15 \\
\hline
\end{tabular}

Table 6 presents the articles on picture books in Asia that received at least one citation. There are 80 articles by Asian authors, but 14 of them are cited at least once at the local level. Hsiao, C.Y. with TLCS 4 is first in rank, followed by Cheng, K.H. and Tsai, C.C. with TLCS 2. The 
remaining 12 articles have a TLCS of 1. Hsiao's (2010) article entitled "Enhancing children's artistic and creative thinking and drawing performance through appreciating picture books" focused on enhancing children's artistic performance and creative thinking by means of picture books. This article was cited 4 times by Taiwanese scholars Cheng and Tsai (2014); Ma and Wei (2016); and Wei and Ma (2017); and Turkish authors Yilmaz, Kucuk, and Goktas (2017).

Cheng and Tsai's (2014) study compared behavioural patterns and cognitive attainment between children's and parents' reading of an augmented reality picture book. Yilmaz, Kucuk, and Goktas (2017) published an article entitled "Are augmented reality picture books magic or real for preschool children aged five to six?" indicating augmented reality picture books are attractive and evocative for children, and they can be used as effective tools to improve preschool children's cognition and listening skills. Ma and Wei's (2016) article examined children's concentration performance on picture books through variables, such as age, gender, and media forms. Wei and Ma (2017) published the article "Influences of visual attention and reading time on children and adults" to investigate the relationship between visual attention and reading time by means of a mobile electroencephalography device. The results of this study found that (a) the visual attention and reading time increases with age; (b) boys' visual attention is superior to that of girls; and (c) multimedia picture books can enhance a boy's visual attention. Apparently, these four articles all centred on visual attention and cognitive development of children who read augmented reality (AR) picture books, also known as multimedia picture books.

Cheng and Tsai's (2014) study was cited by Cheng, and Tsai (2016) and Yilmaz, Kucuk, and Goktas (2017). Cheng, and Tsai cited their own article to investigate "The interaction of childparent shared reading with an AR picture books and parents' conceptions of AR learning." Yilmaz, Kucuk, and Goktas (2017) also cited Cheng, and Tsai's (2014) article most probably because they needed relevant literature to support their AR experiment in preschools.

Table 7 presents the journals that published articles on picture book research, ranked based on the number of articles. The top five journals are: Reading Teacher, followed by Sex Roles, Frontiers in Psychology, Early Childhood Research Quarterly, and First Language. Frontiers in Psychology which published 19 articles, has not garnered any citation score at the local level. The same goes to Early Child Development and Care, with zero TLCS. 
Table 6: Most Cited Articles on Picture book Research in Asia Between 1992 and 2017

\begin{tabular}{|c|c|c|c|}
\hline Rank & Reference to the Article (Authors, Year, Title, Journal, \#Article No) & TLCS & TGCS \\
\hline 1 & $\begin{array}{l}\text { Hsiao, C.Y. (2010). Enhancing children's artistic and creative thinking and } \\
\text { drawing performance through appreciating picture books, International } \\
\text { Journal of Art \& Design Education, } 29 \text { (2): } 143-152 \text {. \#256 }\end{array}$ & 4 & 5 \\
\hline 2 & $\begin{array}{l}\text { Cheng, K.H. \& Tsai, C.C. (2014). Children and parents' reading of an augmented } \\
\text { reality picture book: Analyses of behavioral patterns and cognitive attainment, } \\
\text { Computers \& Education, 72: 302-312. \#400 }\end{array}$ & 2 & 14 \\
\hline 3 & $\begin{array}{l}\text { Stavans, A. (1996). Development of parental narrative input, Journal of } \\
\text { Narrative and Life History, 6(3):253-280. \#40 }\end{array}$ & 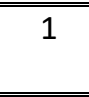 & 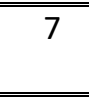 \\
\hline 4 & $\begin{array}{l}\text { Francis, S., Fine, J., \& Tannock, R. (2001). Methylphenidate selectively } \\
\text { improves story retelling in children with attention deficit hyperactivity } \\
\text { disorder, Journal of Child and Adolescent Psychopharmacology, 11(3):217- } \\
\text { 228. \#107 }\end{array}$ & 1 & 31 \\
\hline 5 & $\begin{array}{l}\text { Landau, R., Shusel, B., Eshel, Y. \& Ben-Aaron, M. (2003). Mother-child and } \\
\text { metapelet-child touch behavior with three-year-old kibbutz children in two } \\
\text { contexts, Infant Mental Health Journal, 24(5):529-546. \#132 }\end{array}$ & 1 & 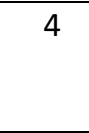 \\
\hline 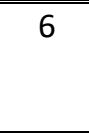 & $\begin{array}{l}\text { Aslan, C. (2010). An analysis of the presentation of Women in } 100 \text { basic literary } \\
\text { works in Turkey Egitim Arastirmalari-eurasian, Journal of Educational } \\
\text { Research, 10(38):19-36. \#245 }\end{array}$ & 1 & 1 \\
\hline 7 & $\begin{array}{l}\text { Scott, R.M., He, Z.J., Bailargeon, R., \& Cummins, D. (2012). False-belief } \\
\text { understanding in 2.5-year-olds: evidence from two novel verbal spontaneous- } \\
\text { response tasks, Developmental Science, 15(2):181-193. \#318 }\end{array}$ & 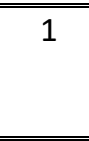 & 37 \\
\hline 8 & $\begin{array}{l}\text { Foroutan, Y. (2012). Gender representation in school textbooks in Iran: The } \\
\text { place of languages, Current Sociology, 60(6): 771-787. \#337 }\end{array}$ & 1 & 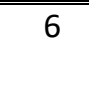 \\
\hline 9 & $\begin{array}{l}\text { Yang, C.C., Hwang, G.J., Hung, C.M., \& Tseng, S.S. (2013). An Evaluation of the } \\
\text { learning effectiveness of concept map-based science book reading via mobile } \\
\text { devices, Educational Technology \& Society, 16(3):167-178. \#370 }\end{array}$ &  & 19 \\
\hline 10 & $\begin{array}{l}\text { Liu, H.M. (2014). Lexical and acoustic features of maternal utterances } \\
\text { addressing preverbal infants in picture book reading link to 5-year-old } \\
\text { children's language development, Early Education and Development, } \\
25(8): 1103-1117 . \# 387\end{array}$ & 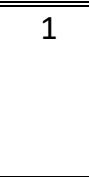 & 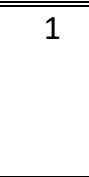 \\
\hline 11 & $\begin{array}{l}\text { Gonen, M., Uludag, G., Tanribuyurdu, E.F., \& Tufekci, E. (2014). The } \\
\text { examination of children's picture books' Features for 0-3-year-olds, Hacettepe } \\
\text { Universitiesi Egitim Fakultesi Dergisi-Hacettepe University, Journal of } \\
\text { Education, 29(1):126-139. \#390 }\end{array}$ & 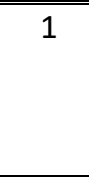 & 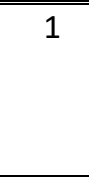 \\
\hline 12 & $\begin{array}{l}\text { Stone, T.E., \& Levett-Jones, T. (2014). A comparison of three types of stimulus } \\
\text { material in undergraduate mental health nursing education, Nurse Education } \\
\text { Today, } 34 \text { (4):586-591 \#409 }\end{array}$ & 1 & 4 \\
\hline 13 & $\begin{array}{l}\text { Murayama, Y. Ohba, H. Yasunaga, M., Nonaka, K., Takeuchi, R., et. al. (2015). } \\
\text { The effect of intergenerational programs on the mental health of elderly } \\
\text { adults, Aging \& Mental Health, 19(4):306-314. \#459 }\end{array}$ & $\overline{c 1}$ & $\bar{~} 9$ \\
\hline 14 & $\begin{array}{l}\text { Park, M.K., Park, J.Y., Nicolas, G., Paik, H.Y., Kim, J., et. al. (2015). Adapting a } \\
\text { standardized international } 24 \mathrm{~h} \text { dietary recall methodology (GloboDiet } \\
\text { software) for research and dietary surveillance in Korea, British Journal of } \\
\text { Nutrition, } 113(11): 1810-1818 . \# 468\end{array}$ & $\overline{c 1}$ & 5 \\
\hline
\end{tabular}

Table 8 lists the most cited journals ranked based on their TLCS. The top five most cited journals are Sex Roles (TLCS 101), followed by Developmental Psychology, Journal of Cognition and Development, Child Development, and Early Childhood Research Quarterly. Journal of Social Behavior and Personality, although recorded only one article on picture 
book research, is in the most cited journal list (TLCS 15). This finding reflects that journals publishing more articles on picture book research might not necessarily yield a higher TLCS.

Table 7: Journals Publishing Articles on Picture Book Research Indexed in the Web of Science (1992-2017)

\begin{tabular}{c||l|c||c|c}
\hline \hline \multicolumn{1}{|c|}{ Journal Title } & Articles & TLCS & TLGS \\
\hline 1 & Reading Teacher & 45 & 24 & 151 \\
\hline 2 & Sex Roles & 21 & 101 & 362 \\
\hline \hline 3 & Frontiers in Psychology & 19 & 0 & 119 \\
\hline 4 & Early Childhood Research Quarterly & 13 & 36 & 434 \\
\hline 5 & First Language & 11 & 3 & 46 \\
\hline \hline 6 & Journal of Adolescent \& Adult Literacy & 9 & 10 & 74 \\
\hline 7 & Child Development & 8 & 37 & 180 \\
\hline \hline 8 & Language Speech and Hearing Services in Schools & 8 & 23 & 243 \\
\hline 9 & Literacy & 8 & 2 & 20 \\
\hline \hline 10 & Developmental Psychology & 7 & 82 & 643 \\
\hline \hline 11 & Journal of Child Language & 7 & 16 & 218 \\
\hline \hline 12 & Journal of Experimental Child Psychology & 7 & 22 & 82 \\
\hline \hline 13 & Journal of Literacy Research & 7 & 7 & 34 \\
\hline \hline 14 & Young Children & 7 & 5 & 33 \\
\hline \hline 15 & British Journal of Developmental Psychology & 6 & 23 & 211 \\
\hline \hline 16 & Child Language Teaching \& Therapy & 6 & 1 & 26 \\
\hline \hline 17 & Early Child Development and Care & 6 & 0 & 3 \\
\hline \hline 18 & Journal of Cognition and Development & 5 & 46 & 156 \\
\hline \hline 20 & Appetite & Applied Psycholinguistics & 4 & 70 \\
\hline \hline 22 & Early Education and Development & 5 & 16 & 188 \\
\hline \hline
\end{tabular}

Of the 65 journals publishing articles on picture book research by Asian authors, only six are listed in Table 7 and Table 8. They are: Early Child Development and Care, Early Education and Development, English Teaching-Practice and Critique, Journal of Adolescent \& Adult Literacy, Frontiers in Psychology, and Sex Roles. Taiwanese authors have published in the 
first aforementioned journals, one Turkish author published an article in Early Child Development and Care and the Mainland Chinese authors have published in Sex Roles. To be more specific, four articles were published in Frontiers in Psychology, two by Japanese authors and another two by authors from Mainland China. Frontiers in Psychology is listed in Table 7, but it is not listed in Table 8; therefore, it is hard to judge to what extent the influence of this journal may be on picture book research in this case. It might be the Asian authors' preferred journal in terms of publication; however, it might be the least influential one in terms of internationalization.

Table 8: Most Cited Journals Publishing Articles on Picture book Research by their Total Local Citation Score (1992-2017)

\begin{tabular}{|c|c|c|c|c|}
\hline Rank & Journal Title & Articles & TLCS & TLGS \\
\hline 1 & Sex Roles & 21 & 101 & 362 \\
\hline 2 & Developmental Psychology & 7 & 82 & 643 \\
\hline 3 & Journal of Cognition and Development & 6 & 46 & 156 \\
\hline 4 & Child Development & 8 & 37 & 180 \\
\hline 5 & Early Childhood Research Quarterly & 13 & 36 & 434 \\
\hline 6 & Reading Teacher & 45 & 24 & 151 \\
\hline 7 & British Journal of Developmental Psychology & 6 & 23 & 211 \\
\hline 8 & Language Speech and Hearing Services in Schools & 8 & 23 & 243 \\
\hline 9 & Journal of Experimental Child Psychology & 7 & 22 & 82 \\
\hline 10 & Applied Psycholinguistics & 5 & 16 & 188 \\
\hline 11 & Journal of Applied Developmental Psychology & 3 & 16 & 86 \\
\hline 12 & Journal of Child Language & 7 & 16 & 218 \\
\hline 13 & Gender \& Society & 4 & 15 & 87 \\
\hline 14 & Journal of Social Behavior and Personality & 1 & 15 & 22 \\
\hline 15 & Journal of Educational Psychology & 2 & 14 & 200 \\
\hline 16 & International Journal of Language \& Communication Disorder & 3 & 13 & 195 \\
\hline 17 & Reading Research Quarterly & 3 & 12 & 140 \\
\hline 18 & Social Development & 4 & 12 & 155 \\
\hline 19 & Journal of Adolescent \& Adult Literacy & 9 & 10 & 74 \\
\hline
\end{tabular}

In these 65 journals publishing articles on picture book research by Asian authors, the journals related to the multimedia computer, computer-assisted learning and technology education, were found. For example, British Journal of Educational Technology, Computers \& Education, Educational Technology \& Society, Eurasia Journal of Mathematics Science and 
Technology Education, Journal of Computer Assisted Learning, RECALL, Computer Vision and Image Understanding, and Computers \& Graphics were all listed. There are six similar journals originating from Taiwan, one in Japan, and two in Turkey. With the exception of duplications, there are a total of nine journal titles listed, accounting for 15 percent of all published journals with Asian authors present. Apparently, the use of multimedia computer in picture book reading is an important issue in Asia, and this issue is seen as quite different from conventional picture book research.

\section{Mapping the Development of Core Themes on Picture Book Research (a) Mapping the Core Themes in the World}

Figure 2 presents a visual representation of about 50 of the top most cited articles for the past 26 years and extracted by their Local Citation Scores (LCS) in the 295 journals reviewed and in the direct citations made between those articles. In Figure 2, the vertical axis represents the timeline from 1992 to 2017 with the number of papers published; each node representing a top-50 heavily-cited article within the WoS database. The size of the circle of each node shows its influence and importance on picture book research extracted by its LCS. In short, the bigger the node the more important it may become. As shown in Figure 2, there are four core clusters in which three, and above-three, nodes are connected by arrows: The first cluster contains nodes [8], [27], [29], [21], and [38]; the second cluster is related to gender equity in the picture books that aggregates important article nodes [11] [41] [51] [79] [136] [154] [179] [181]; the third cluster includes nodes [178], [188], [196], [237], [261], [291], and [292]; and, the fourth one consists of nodes [33], [37], [71], and [129].

Based on Figure 2, the first cluster formed by important articles [8], [27], [29], [21], and [38] appears, forming a language teaching issue specific to reading intervention for young children in early childhood. According to the articles presented, picture book reading intervention in day-care and low income families will facilitate young children to develop their first language and to improve the young reader's level of cognition. From 1992 to 1995, reading intervention in conjunction with picture books has been proven to have a farreaching impact on readers' language development, reading comprehension, and cognitive development, especially as it relates to adults and children, or parents and children who are sharing picture books.

Gender equity has been mentioned in journal articles related to picture books since 1993. In the second cluster, article [11] has profound impact on [41] and [51] in 1996, [79] in 1999, [136] in 2004, [154] in 2005, [179] in 2006, and [181] in 2011. Sex Roles, considered to be the most important journal, maintains the highest LCS, as shown in its top placement in Tables 7 and 8, respectively. Gender roles in picture books have been shown to influence 
cognitive development of young children deeply. To examine gender stereotypes in picture books, the authors of these articles have paid close attention to gender differences and gender equity depicted from the twentieth century's most popular picture books, which might contain inequitable plots, emotional language, and an under-representation of female characters.

In the third cluster, toddlers' comprehension through illustrations in picture books and knowledge transfer is represented. Since 2006, article [178] impacted [188] in 2007, [196] in 2008, [237] in 2009, [261] in 2010, and [291] and [292] in 2011; so, these articles have generated an issue related to improving toddlers' comprehension skills as derived from illustrated books. For example, Simcock, and Deloache (2006) found that toddlers would imitate specific target actions on the basis of perceived picture book interactions. Ganea, Pickard, and Deloache (2008) paid attention to the method of how young children transfer information learned from picture books into real life post-reading. Ganea et al. (2009) confirmed that images found in picture books are referential in such a way that toddlers can represent objects in the real world from that original source.

The fourth cluster shows a specific relationship to special education topics and picture books, and it contains four articles. Tager-Flusberg (1995) [33] investigated autistic children's' story narration techniques and Tagerflusberg and Sullivan (1995) [37] continued to compare the narratives produced by autistic and mentally-retarded individuals. Although these two articles are self-cited, they have already had to a certain extent, influenced future research. For example, they influenced [71] in 1998 and [129] in 2003. Charman and Shmueli-Goetz (1998) conducted an experimental study to examine what if any relationship might exist between a theory of mind, language ability, and narrative discourse; Norbury and Bishop (2003) investigated the narrative skills of children who possess light-to-moderate communication impairment. Similarly, picture book reading is seen as not the only effective means for normally-developing children to gain comprehension, but it can also enhance the narrative ability of autistic children and those who are seen to have communicative impairments. 


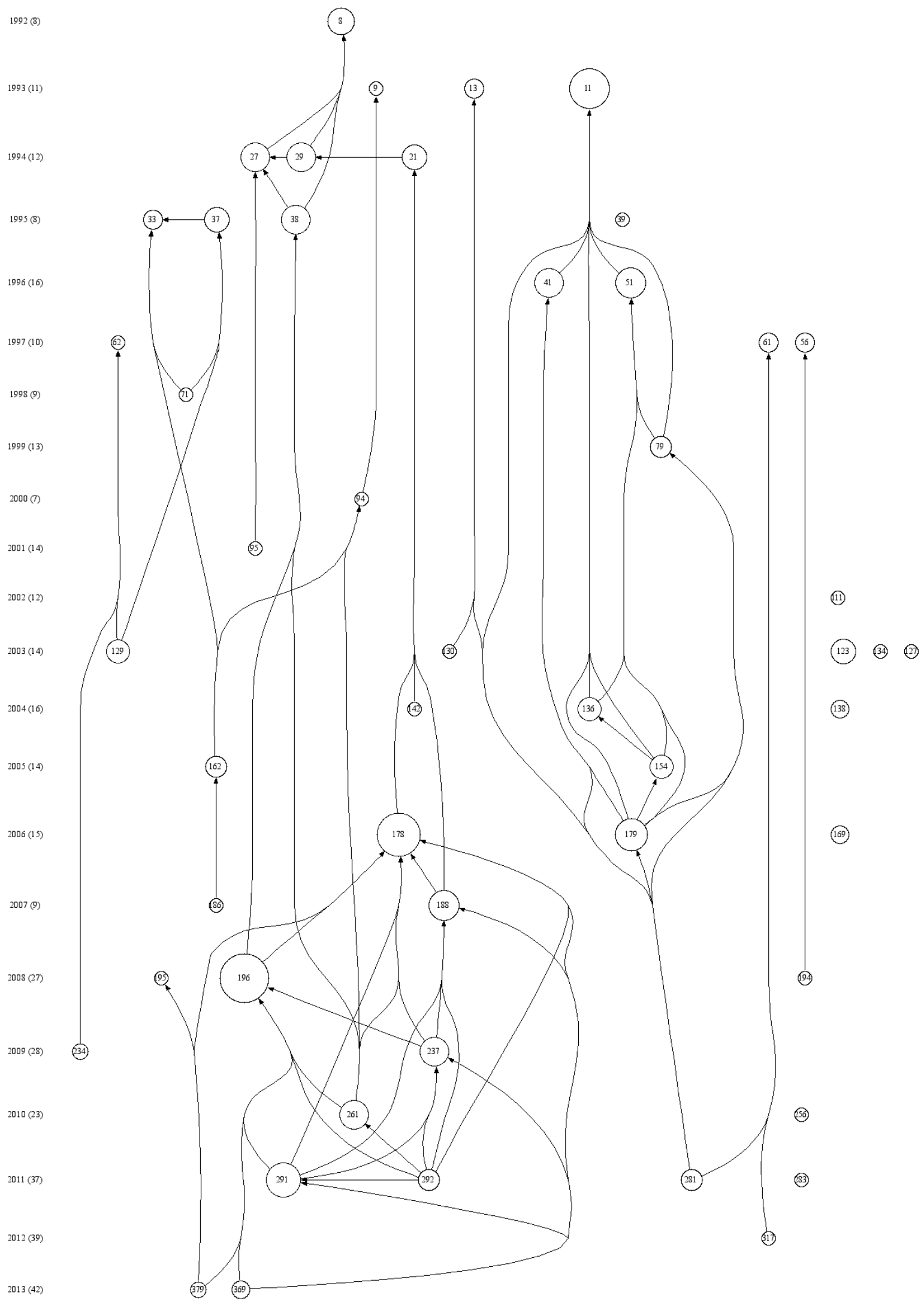

Figure 2. Most Cited Articles (Nodes: 50; Links: 71; LCS, Min: 4, Max: 40 (LCS Scaled) 


\section{(b) Mapping the Core Themes in Asia}

To map the core themes in Asia, the 80 articles by Asian authors are sorted by their countriesof-origin and then listed in chronological order. Each country seems to have its own selective preference for picture book research. The research interests in each country are remarkably different from one to another. Among the 12 Asian countries, Turkey published the first article on picture books in 1992 in an effort to discuss issues concerned with drawing 3-D graphic mapping in topological picture books. However, there were no publications in Turkey until 2003, thus, there were only 2 papers published prior to 2000. From 2010 to 2017, 12 articles were published in total. Taiwan recorded 20 articles and was first in rank. Japan published 17 papers, and it was ranked second in Asia. From the first article of 1994, a total of 4 articles were published by the end of 2000 . China recorded 10 related articles, ranking it as fourth; the first paper was published in 2011. A total of 7 papers were published by Israel; the earliest one was published in 1996. South Korea recorded the earliest paper published in 2013, and it has a total of 6 papers. Singapore published 2 papers, one each in 2011 and 2014 respectively. Another 2 papers were published in Cyprus; similarly, one was published in 2010 and the other in 2016. Other countries such as Malaysia, Indonesia, Pakistan, Iran, each published a single article.

Based the contents of the 80 articles under study, they could be categorized into 9 basic themes, as follows: Education; Computer-assisted education and educational technology; Special education; Early childhood education; Educational psychology; Sociology/ culture; Health care/nursing; Gender issues; and Language education. After an analysis of the number of articles, the top 5 themes become: Early childhood education; Educational psychology; Language education (first or second language education); Computer-assisted education and educational technology; and Gender issues.

Picture books may be utilized as important teaching materials in early childhood education. Turkey published 5 articles directly related to preschool education; Israel published 3 articles related to the topic of preschool children's narrative construction. Taiwanese, South Korean, and Cypriot researchers also focused on the effects of picture books related to preschoolaged children.

Research in educational psychology, the fundamental second theme, is broadly seen in the 80 articles represented. Akita and Muto (1996) investigated mothers' conceptions about why they may choose to read picture books to their children. Parental reading-aloud could influence young children's cognitive development (Hsiao 2010), comprehension (Lee 2016), knowledge transfer, and even mathematics performance (van Den Heuvel-Panhuizen, Elia, and Rpbitzsch 2016). 
The third core theme, language education, especially first language and second/foreign language acquisition, is always an important objective for language teachers who use picture books as source materials in schools. For first language acquisition, parental input, for example as with mother's picture book reading, plays a crucial role in children's language development (Stavans 1996). Picture books integrated into group reading activities serves to enhance students' learning effectiveness and attitudes (Lin et al. 2014). The multiple readerships of picture books is embodied in Sun's (2015) study on picture book lessons for young adult English as Foreign Language (EFL) learning and in Ping's (2014) research on language learning context in preschool settings.

The fourth core theme, computer-assisted education and educational technology, is found in most of Taiwan's 20 articles which are focused on computer-assisted picture book reading or with digital picture books as the basis of teaching materials, although conventional reading instruction and cognitive development are similarly discussed. The discussions on AR picture books are a prevalent research feature in Asia. Cheng and Tsai (2014) conducted their study on children and parents' behavioural patterns and cognitive attainment during their reading of AR picture books. In 2016, they continued to investigate the interaction of child-parent shared reading with an AR picture book (Cheng and Tsai 2016). Hung, Chen, and Huang's (2017) research suggested that AR picture books, as a different teaching material, can enhance learning. Yilmaz, Kucuk, and Goktas (2017) implemented AR picture books for age five to six year olds in preschool. In addition to AR, other types of picture books are also mentioned. Masataka's (2014) article suggested that intensive exposure to a digital picture book will enhance readers' reading ability. Frequent design of applications related to children's electronic pictures is also an essential part of an innovative learning environment (Yang and Ho, 2017).

The fifth core theme relates to gender issues, such as with gender stereotypes and gender equity. Chen and Rao (2011) suggested that teachers' contributions on gender socialization in Chinese Kindergartens directly impacts children through picture book representations delivered by educators. In fact, it is necessary to investigate gender representation in other reading materials, such as textbooks (Foroutan 2012) and picture books, which convey gender messages to young children (Nair and Rosli 2013). Liang, O'Halloran, and Tan (2016) explored the metaphors used for sex education in picture books from China. Yang (2011) examined gender stereotypes in a primary school English language textbook series from Hong Kong. 
Wu, J.F.

In summary, the top four themes presented relate to the key issues of the world-wide picture book research from 1992 to 2017, whereas the five core themes emerged from the 80 articles from Asia. Two themes, gender issues and language teaching/education are held in common. Regarding early childhood education, Asian authors placed emphasis on the learning effectiveness of picture book reading among pre-adolescents. After 2015, teaching with educational technology has become an innovative approach for language arts. Thus, computer-based multimedia, such as e-picture books (electronic picture books and digital picture books), were used in teaching or parent-child reading settings. Educational psychology research in Asia reveals that Asian authors pay more attention to young children's cognitive development, parental beliefs, and teachers' conceptions about picture book reading.

\section{DISCUSSIONS}

The findings of this study leads to the following important discussions. First, it is necessary to rethink the importance and representations of TLCS. In terms of Bradford's law (Egghe and Rousseau 2007), quality articles can easily be identified in core journals since a higher TLCS of an article reflect the impact of the research or its influence. Results show that only a few articles authored by Asian authors on this subject were published in the most cited journals. Although the number of theme-specific publication on picture books in Asia reached 80 articles, the TLCS of each article was considered to be low. The 80 articles by Asian authors were published in 65 journals. That is, most Asian scholars did not consider the TLCS of an article or a journal prior to submitting their manuscripts for publication. In this case, authors in Asia may consider publishing their articles in the most cited journals listed in this study for the possibility to increase the TLCS of their own articles.

On the other hand, these most cited journals merely represent the world-wide trend of picture book research instead of paying particular attention to the research featured in the context of Asia. This study highlighted that Asian research on picture books is often characterized by topics on computer-assisted instruction and educational technology, for example, reading digital picture books or AR picture books has become another research feature in Asia from 2014 onwards. However, such a potential issue is still not seen to be part of the four core themes world-wide identified in this research. Picture book reading is no longer a conventional way of reading and its form can also become more accessible and more attractive while integrating content with computer and multimedia applications. Journals with the aim and scope related to computer and educational technology are likely to become the most cited ones in the future with the trend of implementing computer-assisted 
instructions becoming more evident.

Secondly, gender issues, including gender equity, gender differences and gendered stereotypes, are another interesting theme for authors to integrate into picture book reading research. Gender equity mentioned earlier by its inclusion in the research found in western countries is recently advocated both for and by Asian scholars, especially in countries such as Iran and Malaysia, where Islam is the dominant religion. The conceptions of gender equity centre on mutual respect between males and females, especially in light that the gender differences obviously exist. For example, AR picture books and multimedia picture books are more attractive to boys than girls and learning results are better for boys according to Turkish authors in 2017 (Yilmaz, Kucuk and Goktas 2017). Teaching effectiveness would be improved by teaching students in accordance with their genderspecific differences (Liang, O'Halloran and Tan 2016). Gendered stereotypes embedded in popular picture books have a crucial impact on young children; therefore, identifying and eliminating gender stereotypes that are frequently found in publications in Asia would be greatly facilitated. In sum, gender equity is the ultimate educational goal for humanity and educators and scholars have to examine gendered stereotypes in picture books constantly in order to prevent young children from absorbing their negative effects.

Third, age is also a key factor affecting the effectiveness and comprehension of reading with picture books. In recent years, many studies have explored teaching effectiveness of picture books when used by adults to enhance language proficiency and to broaden their worldviews (Bang 2000; Murayama et al. 2015; An, Wang, and Sun 2017; Wei and Ma, 2017). It can be seen that in the past few years, the readerships of picture books have expanded according to their representative age groups, and they are no longer confined to be used solely by young children and their parents. For adults, the purpose of reading picture books is often for recreation or obtaining information rather than in learning to read. Adult picture books, a new genre, could be seen as an emerging trend of picture book research in Asia.

\section{CONCLUSIONS}

This bibliometric study has compared trends in world-wide picture book research from 1992 to 2017 as they relate to the development of Asian countries' picture books based on an analysis of five major issues. Derived from the statistically analyzed data, four important world themes were explored: children's reading intervention programmes (parent-child Interactive reading); children's understanding of picture books through means of their illustrations; picture books applied to special education settings; and gender issues. 
Based on the 80 papers originated from 12 Asian countries, five core research themes were developed: early childhood education; educational psychology; language education (first or second language education); computer-assisted education and educational technology; and gender issues. Based on these core Asian themes, the development of picture book research from 1992 to 2017 may differ from one country to another since research preferences, as well as research considerations, may differ from country-to-country.

The implications of this study are threefold. Firstly, they lie in the review that picture books are a genre to convey the profound contents of children's literature. From a macroscopic point of view, picture books can lead young readers into the wonder of children's literature, a realm where they are able to acquire languages, appreciate art, obtain abundant knowledge, and even receive psychological counseling. The impact of picture books on child development is proven to be crucial. Secondly, the study found that Asian authors who published articles related to picture books selected to feature computer-assisted instruction and educational technology according to their research preference. Inspired by the results of this study, future research may contribute towards visualizing the development of picture book research from Africa, South America, Europe, and Oceania, for further investigation of several unique characteristics found in picture books. Thirdly, since multi-levelled readerships of picture books emerge from the findings of this study, future research may be conducted regarding adult picture book distribution, evaluative adult reading programmes utilizing picture books, and the inherent learning effects of adult picture books. For Asian scholars, follow-up studies could stress the readerships of e-picture books, digital picture books, and AR picture books in order to explore the feasibility of this alternative form of picture books for readers of all ages.

\section{ACKNOWLEDGEMENT}

This research received no specific grant from any funding agency in the public, commercial, or not-for profit sectors. The author sincerely thanked the reviewers for their helpful suggestions to improve the article. 


\section{REFERENCES}

Akita, K. and Muto, T. 1996. Why do mothers read picture-books to their children?: Mothers' conceptions and their setting environment on reading. Journal of Educational Psychology, Vol. 44: 109-120.

An, L., Wang, Y. and Sun, Y. 2017. Reading words or pictures: Eye movement patterns in adults and children differ by age group and receptive language ability. Frontiers in Psychology, Vol. 8, no. 791.

Bang, M. 2000. Picture this: How pictures work. CA: Chronicle Books.

Charman, T., and Shmueli-Goetz, Y. 1998. The relationship between theory of mind, language and narrative discourse: an experimental study. Cahiers de Psychologie Cognitive/Current Psychology of Cognition, Vol.17, no. 2: 245-271.

Chen, E. S. L. and Rao, N. 2011. Gender socialization in Chinese kindergartens: Teachers' contributions. Sex Roles, Vol. 64, no. 1-2: 103-116.

Chen, L. and Pan, N. 2009. Development of English referring expressions in the narratives of Chinese-English bilinguals, Bilingualism-language and Cognition, Vol.12, no.4: 429-445.

Cheng, K.-H. and Tsai, C.-C. 2014. Children and parents' reading of an augmented reality picture book: Analyses of behavioral patterns and cognitive attainment. Computers \& Education, no. 72: 302-312.

Cheng, K. H., and Tsai, C. C. 2016. The interaction of child-parent shared reading with an augmented reality (AR) picture book and parents' conceptions of AR learning. British Journal of Educational Technology, Vol. 47, no. 1: 203-222.

Danis, A., Bernard, J. M. and Leproux, C. 2000. Shared picture-book reading: A sequential analysis of adult-child verbal interactions. British Journal of Developmental Psychology, Vol.18, no.3: 369-388.

Devescovi, A., and Baumgartner, E. 1993. Joint-reading a picture book: Verbal interaction and narrative skills. Cognition and Instruction, Vol.11, no.3-4: 299-323.

Egghe, L. and Rousseau, R. 2007. Averages of impact factors: General contribution. South African Journal of Libraries and Information Science, Vol.73, no.1: 84-89.

Foroutan, Y. 2012. Gender representation in school textbooks in Iran: The place of languages. Current Sociology, Vol. 60, no.6: 771-787.

Ganea, P. A., Preissler, M. L., Butler, L., Carey, S. and DeLoache, J. S. 2009. Toddlers' referential understanding of pictures. Journal of Experimental Child Psychology, Vol.104, no.3: 283295.

Ganea, P. A., Ma, L., and DeLoache, J. S. 2011. Young children's learning and transfer of biological information from picturebooks to real animals. Child Development, Vol. 82, no.5: 1421-1433.

Ganea, P. A., Pickard, M. B., and DeLoache, J. S. 2008. Transfer between picturebooks and 
the real world by very young children. Journal of Cognition and Development, Vol. 9, no.1, 46-66.

Gorman, B.K., Fiestas, C. E., Peña, E. D., and Clark, M. R. 2011. Creative and stylistic devices employed by children during a storybook narrative task: A cross-cultural study. Language Speech and Hearing Services in Schools, Vol. 42, no.2: 167-181.

Hsiao, C. Y. 2010. Enhancing children's artistic and creative thinking and drawing performance through appreciating picture books. International Journal of Art \& Design Education, Vol.29, no.2: 143-152.

Lee, Y. J. 2016. Letting the story out: Drawing on children's life stories and identities to help them read beyond and enhance their comprehension. Journal of Language Identity and Education, Vol. 15, no.6: 389-403.

Liang, J. Y., Tan, S. and O'Halloran, K. 2017. Representing sexuality and morality in sex education picture books in contemporary China. Social Semiotics, Vol. 27, no.1: 107-126.

Lin, C. P., Chen, W., Yang, S. J., Xie, W. and Lin, C. C. 2014.. Exploring students' learning effectiveness and attitude in $\mathrm{G}$ roup $\mathrm{S}$ cribbles-supported collaborative reading activities: a study in the primary classroom. Journal of Computer Assisted Learning, Vol,30, no.1, 68-81.

Ma, M. Y. and Wei, C. C. 2016. A comparative study of children's concentration performance on picture books: age, gender, and media forms. Interactive Learning Environments, Vol. 24, no. 8: 1922-1937.

Masataka, N. 2014. Development of reading ability is facilitated by intensive exposure to a digital children's picture book. Frontiers in Psychology, Vol. 5, no. 396. doi: 10.3389/fpsyg.2014.00396.

Murayama, Y., Ohba, H., Yasunaga , M., Nonaka, K., Takeuchi, R. and Nishi, M. 2015. The effect of intergenerational programs on the mental health of elderly adults. Aging \& Mental Health, Vol. 19, no.4: 306-314.

Nair, R., and Rosli, T. 2013. A critical reading of gender construction in Malaysian children's literature How linguistic structures convey deep-rooted gender messages for young children. English Today, Vol.29, no.4: 37-44.

Neuman, S. B., and Celano, D. 2001. Access to print in low-income and middle-income communities. Reading Research Quarterly, Vol. 36, no. 1:8-26.

Norbury, C. F., and Bishop, D. V. M. 2009. Narrative skills of children with communication impairments. International Journal of Language \& Communication Disorders, Vol.38, no.3: 287-313.

Ping, M. T. 2014. Group interactions in dialogic book reading activities as a language learning context in preschool. Learning, Culture and Social Interaction, Vol.3, no.2, 146-158.

Renz, K., Lorch, E. P., Milich, R., Lemberger, C., Bodner, A. and Welsh, R. 2003. On-line story representation in boys with attention deficit hyperactivity disorder. Journal of Abnormal 
Child Psychology, Vol.31, no.1: 93-104.

Sakurai, R., Yasunaga, M., Murayama, Y., Ohba, H., Nonaka, K., Suzuki, Y., Sakuma, N., Nishi, M., Uchida, H., Shinkai, S., and George, R. W. and Fujiwara, Y. 2016. Long-term effects of an intergenerational program on functional capacity in older adults: results from a seven-year follow-up of the reprints study. Archives of Gerontology and Geriatrics, Vol.64: 13-20.

Simcock, G., and DeLoache, J. 2006.. Get the picture? The effects of iconicity on toddlers' reenactment from picture books. Developmental Psychology, Vol. 42, no. 66: 1352.

Stavans, A. 1996.. Development of parental narrative input. Journal of Narrative and Life History, Vol. 6, no. 3: 253-280.

Sun, C.H. 2015. The three little wolves go to college a picture book lesson for young adult EFL learners. Journal of Adolescent \& Adult Literacy, Vol. 59, no.2: 183-195.

Suzuki, H., Kuraoka, M., Yasunaga, M., Nonaka, K., Sakurai, R., Takeuchi, R., Murayama, Y., Ohba, H., and Fujiwara, Y. 2014. Cognitive intervention through a training program for picture book reading in community-dwelling older adults: A randomized controlled trial. BMC Geriatrics, Vol. 14, no. 122. doi: 10.1186/1471-2318-14-122.

Tager-Flusberg, H. 1995. 'Once upon a ribbit':Stories narrated by autistic children. British Journal of Developmental Psychology, Vol. 13, no.1, 45-59.

Tager-Flusberg, H., and Sullivan, K. 1995. Attributing mental states to story characters - A comparison of narratives produced by autistic and mentally-retarded individuals. Applied Psycholinguistics, Vol. 16, no.3: 241-256.

Van Eck, N., and Waltman, L. 2009.. Software survey: VOSviewer, a computer program for bibliometric mapping. Scientometrics, Vol.84, no.2, 523-538.

van Den Heuvel-Panhuizen, M., Elia, I. and Robitzsch, A. 2016. Effects of reading picture books on kindergartners' mathematics performance. Educational Psychology, Vol,36, no.2, 323-346.

Wei, C. C., and Ma, M. Y. 2017.. Influences of visual attention and reading time on children and adults. Reading \& Writing Quarterly, Vol. 33, no. 2: 97-108.

Yang, C. C. R. 2011.. Gender representation in a Hong Kong primary English textbook series: The relationship between language planning and social policy. Current Issues in Language Planning, Vol. 12, no.1, 77-88.

Yang, J.K. and Ho L.K. 2018. Study of the interface design of app children's electronic picture book. Agro Food Industry Hi-Tech. Vol.28, no.3: 3303-3305.

Yilmaz, R. M., Kucuk, S., and Goktas, Y. 2017. Are augmented reality picture books magic or real for preschool children aged five to six? British Journal of Educational Technology, Vol.48, no.3: 824-841. 